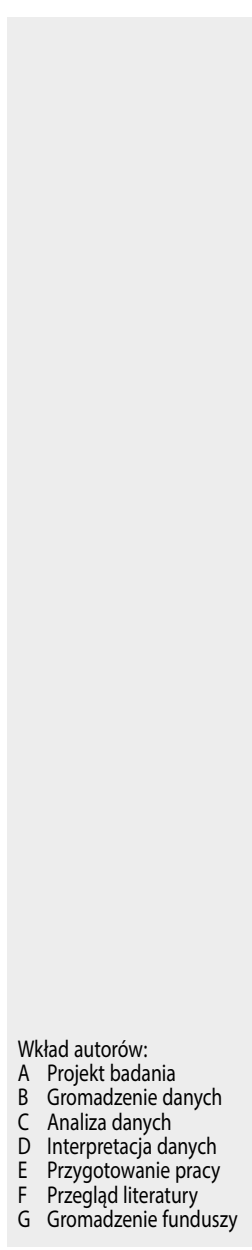

\title{
Leczenie zaburzeń słuchu za pomocą wszczepialnych implantów słuchowych (na przewodnictwo kostne, ucha środkowego) - potrzeby, dostępność w różnych regionach Polski
}

\section{Treatment of hearing disorders with implantable devices (for bone conduction, middle ear) - needs, availability in different regions of Poland}

\author{
Henryk Skarżyński ${ }^{1 \mathrm{EG}}$, Elżbieta Włodarczyk ${ }^{1 \mathrm{EF}}$, Justyna Kutyba ${ }^{1 \mathrm{CDEF}}$, \\ Bartosz Stawowski ${ }^{2 B C}$, Jędrzej Bartosik ${ }^{1 \mathrm{D}}$, Anna Ratuszniak ${ }^{1 \mathrm{FF}}$, \\ Piotr H. Skarżyński, ${ }^{3,4,5 A E G}$ \\ ${ }^{1}$ Instytut Fizjologii i Patologii Słuchu, Warszawa/Kajetany \\ ${ }^{2}$ Ministerstwo Zdrowia, Departament Analiz i Strategii, Warszawa \\ ${ }^{3}$ Instytut Fizjologii i Patologii Słuchu, Światowe Centrum Słuchu, Zakład Teleaudiologii \\ i Badań Przesiewowych, Warszawa \\ ${ }^{4}$ Warszawski Uniwersytet Medyczny, II Wydział Lekarski, Zakład Niewydolności Serca \\ i Rehabilitacji Kardiologicznej, Warszawa \\ ${ }^{5}$ Instytut Narządów Zmysłów, Kajetany
}

Streszczenie

\begin{abstract}
Wstęp: Niedosłuch jest zaburzeniem występującym coraz częściej u osób w różnym wieku. Główny Urząd Statystyczny szacuje, że w Polsce żyje ok. $6 \mathrm{mln}$ osób, których dotyczy ten problem. Osoby z niedosłuchem mają różne możliwości leczenia. Najczęściej decydują się na klasyczne aparaty słuchowe, jednak nie we wszystkich przypadkach jest możliwość zastosowania takich urządzeń i wtedy pacjent najczęściej jest kwalifikowany do operacji wszczepienia implantu słuchowego.

Cel: Celem pracy była analiza danych opublikowanych przez Ministerstwo Zdrowia w 2016 roku w odniesieniu do chorób nosa, zatok przynosowych, ucha, gardła i krtani w Polsce. Opublikowane dane umożliwiają ocenę dostępności świadczeń zdrowotnych w zakresie implantów ucha środkowego oraz implantów na przewodnictwo kostne udzielanych na terenie całego kraju.

Material i metoda: Analizy dokonano na podstawie map potrzeb zdrowotnych (MPZ) opublikowanych przez Ministerstwo Zdrowia w zakresie chorób nosa, zatok przynosowych, ucha, gardła i krtani. MPZ zostały przygotowane odrębnie dla każdego województwa. Wyniki: Dane dotyczyły hospitalizacji zakończonych w 2014 roku. Według sprawozdania w całym kraju wykonano 227 hospitalizacji, najwięcej w województwie mazowieckim 66 (30\% wszystkich hospitalizacji). Świadczeń udzielono pacjentom w wieku 1-69 lat. Ośrodkiem wiodącym, który przeprowadził najwięcej zabiegów w omawianym zakresie, był Instytut Fizjologii i Patologii Słuchu w Kajetanach. Wnioski: Implanty ucha środkowego oraz zakotwiczone w kości skroniowej są stosunkowo nowymi urządzeniami. Analiza materiału wykazała, że dostępność tego typu urządzeń jest w miarę równomierna na terenie kraju, jednak większość usług związanych z tego typu implantami świadczona jest w województwie mazowieckim.

Słowa kluczowe: implanty ucha środkowego • implanty zakotwiczone w kości • dostępność w Polsce
\end{abstract}

Adres autora: Justyna Kutyba, Instytut Fizjologii i Patologii Słuchu, ul. Mokra 17, 05-830 Nadarzyn, e-mail: j.kutyba@ifps.org.pl 


\section{Abstract}

Introduction: Hearing loss is an increasing prevalence in people of all ages. The Central Statistical Office estimates that there are approximately 6 million people affected in Poland. People with hearing loss have different treatment options. They most often choose classical hearing aids, but not in all cases it is possible to use such devices. In such situations, the patient is usually qualified for hearing implant surgery.

Aim: The aim of the study was to analyse data published by the Ministry of Health in 2016 on diseases of the nose, paranasal sinuses, ear, throat and larynx in Poland. The published data make it possible to assess the availability of health services in the field of middle ear implants and bone conduction implants provided throughout the country.

Material and method: The analysis was based on the Health Needs Maps (HNM) published by the Ministry of Health for diseases of the nose, paranasal sinuses, ear, throat and larynx. The HNMs were prepared separately for each voivodship.

Results: The data concerned hospitalizations completed in 2014. According to the report, 227 hospitalizations was performed in the whole country, the highest number was in the Mazowieckie voivodship - 66 (30\% of all hospitalizations). The services were provided to patients aged 1-69 years. The leading centre which performed the most procedures in this area was the Institute of Physiology and Pathology of Hearing in Kajetany.

Conclusions: Middle ear implants and temporal bone anchored implants are relatively new devices. The material analysis showed that the availability of this type of devices is relatively uniform across the country. However, most of the services related to this type of implants are provided in the Mazowieckie voivodship.

Key words: middle ear implants • bone conduction implants • accessibility in Poland

\section{Wstęp}

Niedosłuch jest zaburzeniem narządu słuchu, które ogranicza percepcję dźwięków, wpływając na zadowolenie i jakość życia pacjentów. W przypadku tego schorzenia zaleca się zaopatrzenie w protezy słuchowe, aby poprawić odbiór dźwięków i zdolności komunikacyjne. Zdarza się jednak, że pacjent nie odczuwa korzyści z użytkowania klasycznych protez słuchowych lub korzyści te nie spełniają jego oczekiwań [1]. W takich sytuacjach z pomocą przychodzi otochirurgia i zabieg wszczepienia aktywnego implantu słuchowego. Implant słuchowy jest elektroniczną wszczepialną lub częściowo wszczepialną protezą narządu słuchu [2]. W zależności od miejsca i sposobu implantacji możemy wyróżnić implanty ślimakowe zakotwiczone w kości skroniowej oraz implanty wszczepiane do ucha środkowego.

W Polsce leczenie całkowitej głuchoty za pomocą implantów słuchowych zapoczątkował prof. Henryk Skarżyński, który w 1992 roku przeprowadził pionierską operację wszczepienia implantu ślimakowego osobie niesłyszącej [3-5]. Był to krok milowy w polskiej otochirurgii, a dokonany postęp dał nadzieję tysiącom osób niesłyszących i stworzył szansę na ich powrót do świata dźwięków oraz na poprawę codziennego funkcjonowania. Program leczenia całkowitej oraz częściowej głuchoty był przełomem w leczeniu i rehabilitacji osób niesłyszących i w efekcie wpłynął na poprawę jakości życia pacjentów. Wraz z pojawieniem się implantów ucha środkowego oraz implantów na przewodnictwo kostne zwiększyła się liczba pacjentów mogących korzystać z wszczepialnych urządzeń wspomagających słyszenie [6-10].

Operacja wszczepiania implantu zakotwiczonego w kości po raz pierwszy w Polsce odbyła się w 1994 roku. Przeprowadził ją prof. Bogdan Rydzewski, który wszczepił osobie dorosłej urządzenie typu BAHA [11]. Instytut Fizjologii i Patologii Słuchu wykonuje takie operacje od 1997 roku. Początkowo leczeniem objęte były dzieci z wrodzonymi wadami ucha środkowego. Wraz z upływem czasu rozszerzono grupy pacjentów, którzy mogą korzystać $\mathrm{z}$ tego typu urządzeń. Obecnie kwalifikowane są również osoby dorosłe oraz dzieci z jednostronną głuchotą. W 2013 roku firma Cochlear stworzyła rozwinięcie klasycznego aparatu BAHA - BAHA Attract. W tym samym roku system ten został wszczepiony przez prof. H. Skarżyńskiego pacjentowi z Polski [12-14]. Urządzenie to różni się od klasycznego BAHA tym, że nie penetruje skóry głowy pacjenta. Zamiast tytanowego zaczepu w skroniowej części głowy umieszczany jest magnes, który utrzymuje procesor mowy. Natomiast w 2012 roku po praz pierwszy w Polsce w klinice Instytutu Fizjologii i Patologii Słuchu w Kajetanach wszczepiono implant na przewodnictwo kostne typu Bonebridge. Zwiększyło to nie tylko możliwości terapeutyczne, lecz także upowszechniło światowe standardy medyczne [6]. W 2003 roku prof. H. Skarżyński przeprowadził operację wszczepienia implantu typu Vibrant Soundbridge do ucha środkowego. Zoperowany został pacjent, który z powodu obustronnej znacznej wady słuchu nie osiągał korzyści z klasycznych aparatów słuchowych. Pionierskie operacje przeprowadzone w Kajetanach były dowodem na to, że pacjenci z Polski jako pierwsi lub jedni $\mathrm{z}$ pierwszych w świecie mają dostęp do najnowszych, najbardziej zaawansowanych technologii medycznych $[3,4]$.

\section{Implanty na przewodnictwo kostne}

Działanie implantów słuchowych zakotwiczonych w kości oparte jest na naturalnej zdolności ciała do przenoszenia wibracji drogą kostną [15-16]. Implant wywołuje

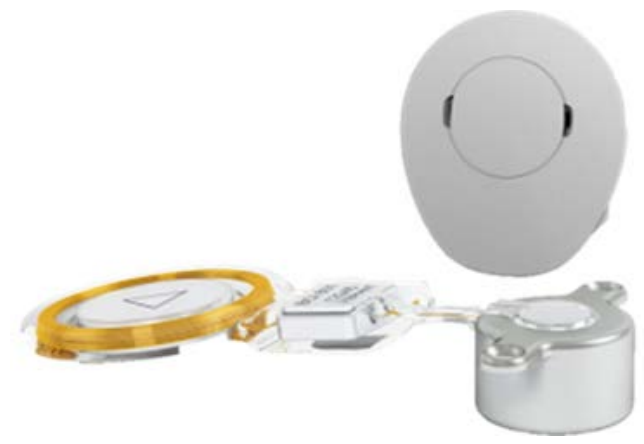

Rycina 1. Budowa implantu firmy MED-EL - Bonebridge [20] Figure 1. Construction of the MED-EL implant - Bonebridge [20] 
drgania, które przez kości czaszki przekazywane są bezpośrednio do ucha wewnętrznego. Urządzenia zakotwiczone w kości możemy podzielić na: penetrujące skórę głowy i niepenetrujące skóry głowy pacjenta. Do pierwszych zalicza się np. system BAHA Connect i PONTO, natomiast do drugich - np. system BAHA Attract oraz Bonebridge [16-18]. Pacjenci decydują się na te urządzenia z kilku przyczyn:

- jakość dźwięku jest lepsza niż w klasycznych aparatach słuchowych,

- urządzenie pozostawia zewnętrzny kanał słuchowy otwarty, co pozwala na wyeliminowanie efektu okluzji,

- urządzenia te zmniejszają prawdopodobieństwo efektu sprzężenia akustycznego w przypadku poważnych uszkodzeń słuchu, które wymagają dużego wzmocnienia za pomocą konwencjonalnych aparatów słuchowych,

- wielu pacjentów woli estetykę tego urządzenia od tradycyjnego aparatu słuchowego, ponieważ małżowina uszna pozostaje wolna, a procesor dźwięku można łatwo ukryć pod włosami [17-19].

\section{Bonebridge}

Implant Bonebridge firmy MED-EL jest urządzeniem częściowo wszczepialnym. Zbudowany jest z części zewnętrznej, którą stanowi procesor dźwięku, oraz części wszczepialnej złożonej z: cewki odbiorczej, magnesu, demodulatora, przewodu i przetwornika BC FMT (ang. Bone Conductive Floating Mass Transducer).

Implant ten znajduje zastosowanie wśród pacjentów dorosłych i dzieci powyżej 5. roku życia, których ubytek słuchu ma charakter przewodzeniowy lub mieszany. Aktualnie implant ten stosuje się u osób z:

- wadami wrodzonymi ucha środkowego oraz współistniejącymi wadami ucha środkowego i zewnętrznego,

- wadami nabytymi: pourazowymi, zarostowymi, które uniemożliwiają korzystanie z klasycznych aparatów słuchowych,

- wrodzoną lub nabytą głuchotą jednostronną, gdy korzyści są większe lub porównywalne niż w protezie typu CROS [21-22].

Dokładne zakresy progów słyszenia, dla których ma zastosowanie omawiane urządzenie, zostały przedstawione na rycinie 2 oraz 3 [6].

\section{Implanty ucha środkowego}

Implanty wszczepiane do ucha środkowego stosowane są głównie wśród pacjentów, którzy z różnych przyczyn nie mogą korzystać z klasycznych aparatów słuchowych [8-9]. Najczęściej są to osoby $z$ wadami wrodzonymi lub nabytymi ucha środkowego i/lub zewnętrznego, cierpiące na przewlekłe zapalenia ucha środkowego i/lub stany zapalne zewnętrznego przewodu słuchowego, a także pacjenci po przebytych operacjach w obrębie ucha środkowego [9]. Implanty ucha środkowego stosuje się również w sytuacjach, gdy pacjent nie odczuwa korzyści z zastosowania klasycznego aparatu słuchowego lub zyski z jego stosowania są niewystarczające [23]. Obecnie implanty

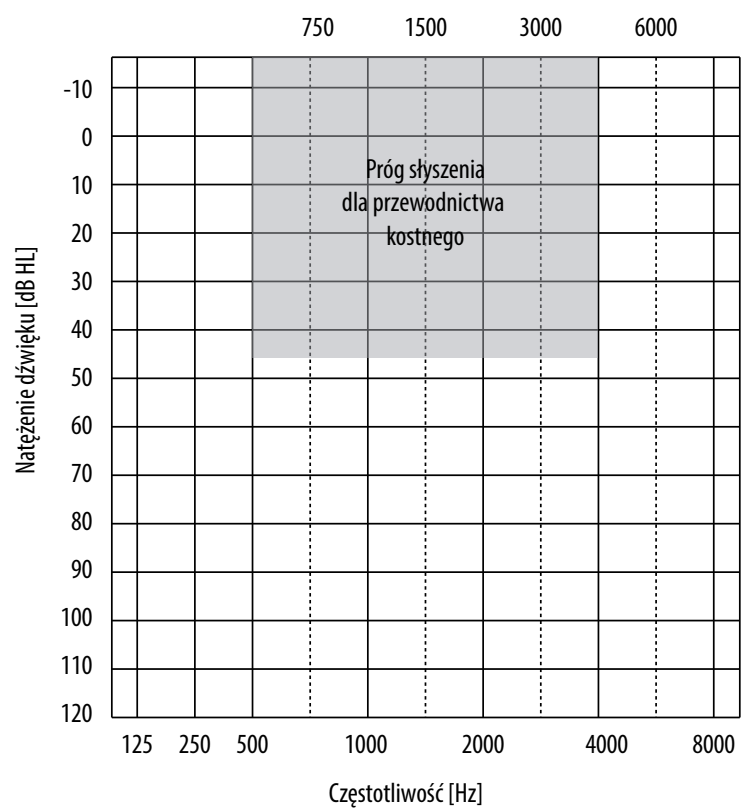

Rycina 2. Zakres wskazań do wszczepienia implantu MED-EL Bonebridge $w$ niedosłuchach typu przewodzeniowego i mieszanego na podstawie badania przewodnictwa kostnego w audiometrii tonalnej [20]

Figure 2. Indications for MED-EL Bonebridge implantation in conductive and mixed hearing loss based on pure--tone bone conduction thresholds [20]

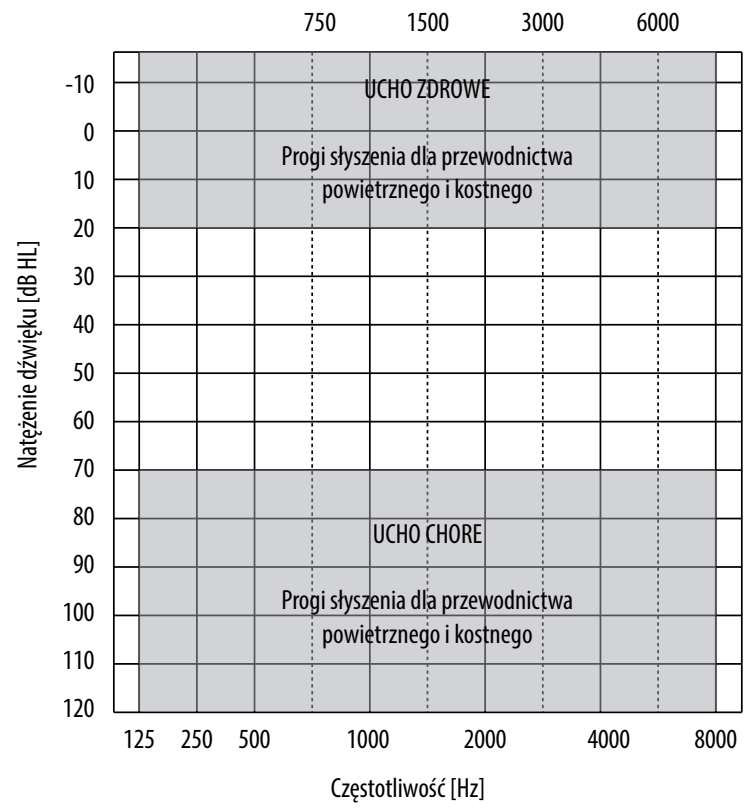

Rycina 3. Zakres wskazań do wszczepienia implantu MED-EL Bonebridge dla przypadków jednostronnej głuchoty [20]

Figure 3. Indications for MED-EL Bonebridge implantation in for cases of unilateral deafness [20]

wszczepiane do ucha środkowego są tak zaawansowane w budowie, że mogą być wykorzystywane do każdego rodzaju niedosłuchu: odbiorczego, przewodzeniowego oraz mieszanego $[8,10]$. Implanty ucha środkowego zostały opracowane jako alternatywa w rehabilitacji klasycznych aparatów słuchowych. Osoby decydujące się na te urządzenia osiągają niejednokrotnie większe korzyści słuchowe 


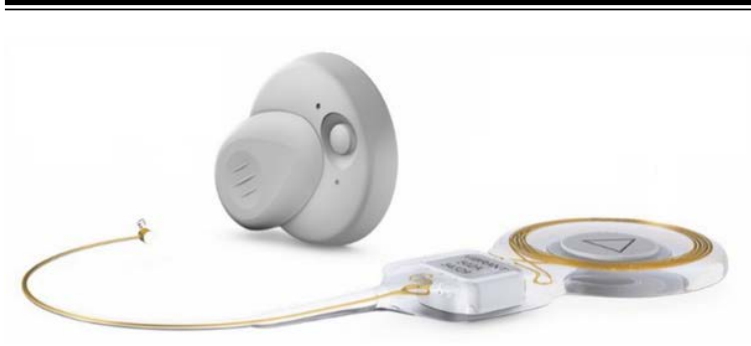

Rycina 4. Budowa implantu firmy MED-EL - Vibrant Soundbridge [20] Figure 4. Construction of the MED-EL implant - Vibrant Soundbridge [20]

niż pacjenci korzystający z klasycznych protez [23-26]. Wyniki opisane w literaturze wskazują, że są to urządzenia bezpieczne, z których zysk funkcjonalny jest wyższy niż w klasycznych protezach. Wzrasta również ogólna jakość życia pacjentów [27].

Istnieje kilka systemów implantów ucha środkowego [28]. Są to między innymi:

- Vibrant Soundbridge firmy MED-EL [10,20],

- MET i CODACS firmy Cochlear [25],

- Esteem firmy Envoy Medical Corporation [24].

Urządzenia te różnią się między sobą budową oraz sposobem działania, w związku z tym odmienne są również kryteria kwalifikacji i technika operacyjna.

\section{Vibrant Soundbridge}

Najczęściej wszczepianym urządzeniem na całym świecie jest implant firmy MED-EL - model Vibrant Soundbridge [20]. Jest to urządzenie częściowo wszczepialne składające się z części zewnętrznej, którą stanowi procesor mowy, oraz części wewnętrznej. Część wewnętrzna - element wszczepialny - złożona jest z: cewki odbiorczej, magnesu oraz demodulatora z przetwornikiem FTM [23]. Rycina 4. przedstawia budowę implantu Vibrant Soundbridge.

Vibrant Soundbridge można stosować w leczeniu operacyjnym osób dorosłych oraz dzieci powyżej 5. roku życia w następujących przypadkach [23,29]:

- wady wrodzone ucha środkowego oraz zewnętrznego,

- wady nabyte ucha środkowego, takie jak: zaawansowana otoskleroza, tympanoskleroza,

- zmiany powstałe na skutek leczenia przewlekłych stanów zapalnych uszu, w przypadku których wcześniejsze operacje rekonstrukcyjne nie przyniosły zamierzonego efektu,

- uszy po przebytych operacjach radykalnych,

- niedosłuch u pacjentów, u których wyniki prób symulacyjnych wskazują na uzyskanie lepszego efektu odbioru dźwięków niż w klasycznych aparatach słuchowych.

Dokładne zakresy progów słyszenia, dla których ma zastosowanie omawiane urządzenie, zostały przedstawione na rycinie 5. oraz 6. [29].

Wraz z ciągłą miniaturyzacją i opracowaniem nowych rozwiązań do implantów ucha środkowego zmieniają się kryteria kwalifikacji pacjentów i zwiększa się grupa osób, które mogą skorzystać z tego typu urządzeń.

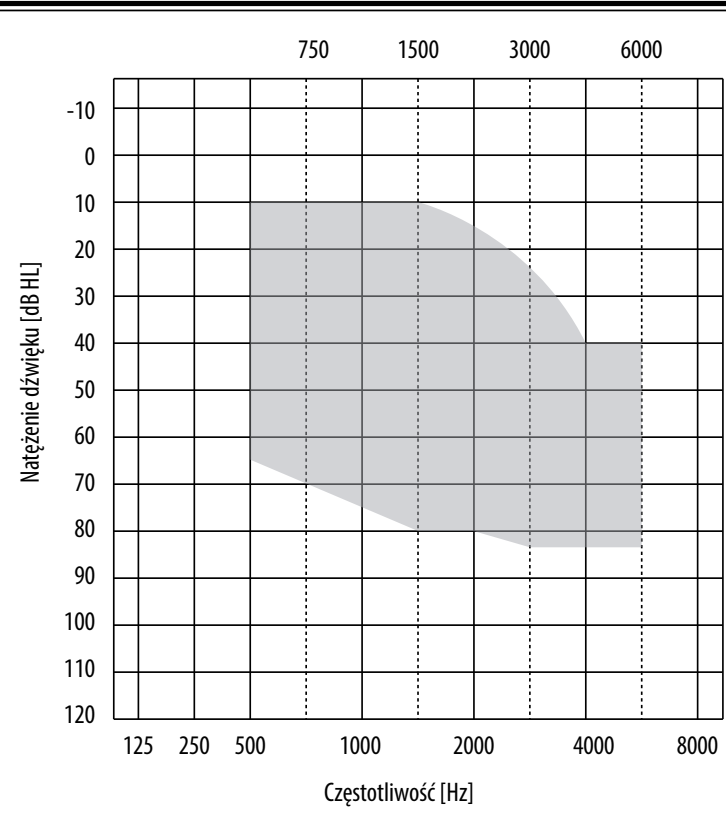

Rycina 5. Zakres wskazań do wszczepienia implantu MED-EL Vibrant Soundbridge dla niedosłuchów typu odbiorczego na podstawie badania przewodnictwa powietrznego $w$ audiometrii tonalnej [20]

Figure 5. Indications for MED-EL Vibrant Soundbridge implantation in sensorineural hearing loss based on pure-tone air conduction thresholds [20]

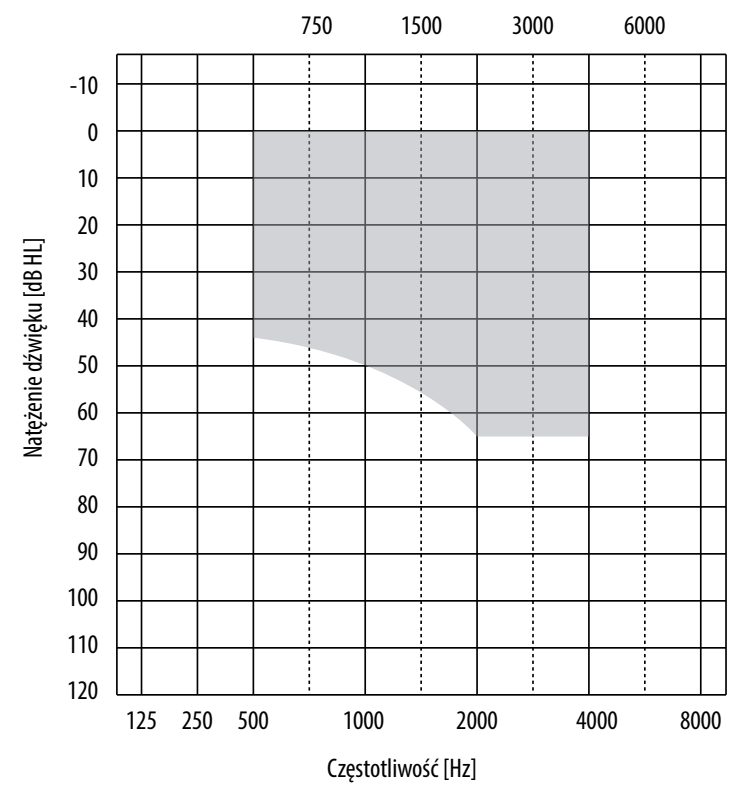

Rycina 6. Zakres wskazań do wszczepienia implantu MED-EL Vibrant Soundbridge dla niedosłuchów typu przewodzeniowego i mieszanego na podstawie badania przewodnictwa powietrznego $w$ audiometrii tonalnej

Figure 6. Indications for MED-EL Vibrant Soundbridge implantation in conductive and mixed hearing loss based on pure-tone bone conduction thresholds

\section{Material}

W grudniu 2016 roku Ministerstwo Zdrowia opublikowało mapy potrzeb zdrowotnych (MPZ) w zakresie chorób nosa, zatok przynosowych, ucha, gardła i krtani. MPZ zostały przygotowane odrębnie dla każdego województwa 
i obejmują dane za rok 2014. Zgodnie z treścią rozporządzenia Ministra Zdrowia mapy składają się z trzech części [30]:

1. Aspekty demograficzne i epidemiologiczne.

2. Analiza stanu i wykorzystania zasobów.

3. Prognozy.

\section{Zabiegi w Polsce w 2014 roku}

W analizie wykorzystano dane jednostkowe o świadczeniach wykazanych przez świadczeniodawców do Narodowego Funduszu Zdrowia (NFZ). W opracowaniu przedstawiono informacje o hospitalizacjach ( $\mathrm{tj}$. o produktach z katalogu 1a oraz 1b), które zakończyły się w 2014 roku i których główną przyczyną były następujące rozpoznania ICD-10: H90 (upośledzenie słuchu przewodzeniowe i czuciowo-nerwowe) i H91 (Inna głuchota), a w ramach hospitalizacji wykonano jedną z procedur ICD-9:

- 20.991 - Wszczepienie / wymiana implantu ucha środkowego,

- 20.993 - Wszczepienie / wymiana innego implantu słuchowego [30].

\section{Wyniki}

W roku 2014 sprawozdano 227 hospitalizacji z powodów wymienionych powyżej. Wyniki opracowywane były na podstawie danych pozyskanych od 23 świadczeniodawców. W tabeli 1. znajduje się zestawienie świadczeniodawców, którzy sprawozdali hospitalizacje $\mathrm{z}$ analizowanego zakresu.

Tabela 1. Zestawienie świadczeniodawców, którzy sprawozdali hospitalizacje z analizowanego zakresu. Kolejność - według liczby wykonanych hospitalizacji [30]

Table 1. List of service providers who reported hospitalizations in the analyzed range. The sequence according to number of hospitalizations [30]

\begin{tabular}{|c|c|c|c|}
\hline Województwo & $\begin{array}{c}\text { Identyfikator } \\
\text { świadczeniodawcy } \\
\text { w MPZ }\end{array}$ & Nazwa świadczeniodawcy & $\begin{array}{c}\text { Liczba sprawozdanych } \\
\text { hospitalizacji } \\
\text { - procedurą } 20.991 \text { lub } \\
20.993\end{array}$ \\
\hline Mazowieckie & 07.0034 & Instytut Fizjologii i Patologii Słuchu & 43 \\
\hline Wielkopolskie & 15.0008 & $\begin{array}{c}\text { Szpital Kliniczny im. Heliodora Święcickiego } \\
\text { Uniwersytetu Medycznego im. Karola } \\
\text { Marcinkowskiego w Poznaniu }\end{array}$ & 30 \\
\hline Śląskie & 12.0068 & Centrum Medyczne Mavit sp. z o.o. & 19 \\
\hline Łódzkie & 05.0002 & Instytut Centrum Zdrowia Matki Polki & 14 \\
\hline Mazowieckie & 07.0005 & Centralny Szpital Kliniczny MSW w Warszawie & 13 \\
\hline Kujawsko-pomorskie & 02.0003 & $\begin{array}{l}\text { Szpital Uniwersytecki nr } 2 \text { im. dr. Jana Biziela } \\
\text { w Bydgoszczy }\end{array}$ & 11 \\
\hline Małopolskie & 06.0012 & SPZOZ 5 Wojskowy Szpital Kliniczny z Polikliniką & 10 \\
\hline Opolskie & 08.0001 & SPZOZ Wojewódzkie Centrum Medyczne w Opolu & 10 \\
\hline Mazowieckie & 07.0001 & SPZOZ Szpital Bielański im. ks. Jerzego Popiełuszki & 9 \\
\hline Podlaskie & 10.0001 & Uniwersytecki Szpital Kliniczny w Białymstoku & 9 \\
\hline Pomorskie & 11.0002 & Uniwersyteckie Centrum Kliniczne & 9 \\
\hline Wielkopolskie & 15.0001 & Wojewódzki Szpital Zespolony w Koninie & 9 \\
\hline Lubelskie & 03.0004 & $\begin{array}{l}\text { Samodzielny Publiczny Szpital Kliniczny nr } 4 \\
\text { w Lublinie }\end{array}$ & 7 \\
\hline Małopolskie & 06.0001 & SPZOZ Szpital Uniwersytecki w Krakowie & 6 \\
\hline Warmińsko-mazurskie & 14.0002 & Wojewódzki Szpital Specjalistyczny w Olsztynie & 6 \\
\hline Warmińsko-mazurskie & 14.0022 & Uniwersytecki Szpital Kloniczny w Olsztynie & 5 \\
\hline Kujawsko-pomorskie & 02.0008 & SPZOZ 10 Wojskowy Szpital Kliniczny z Polikliniką & 4 \\
\hline Kujawsko-pomorskie & 02.0016 & $\begin{array}{c}\text { Wojewódzki Szpital Dziecięcy im. J. Brudzińskiego } \\
\text { w Bydgoszczy }\end{array}$ & 4 \\
\hline Śląskie & 12.0025 & $\begin{array}{c}\text { Samodzielny Publiczny Szpital Kliniczny im. } \\
\text { Andrzeja Mielęckiego ŚUM }\end{array}$ & 3 \\
\hline tódzkie & 05.0009 & $\begin{array}{l}\text { SPZOZ Uniwersytecki Szpital Kliniczny nr } 1 \text { im. } \\
\text { Norberta Barlickiego Uniwersytetu Medycznego }\end{array}$ & 2 \\
\hline Zachodniopomorskie & 16.0003 & $\begin{array}{c}\text { Samodzielny Publiczny Wojewódzki Szpital } \\
\text { Zespolony }\end{array}$ & 2 \\
\hline Mazowieckie & 07.0007 & Samodzielny Publiczny Centralny Szpital Kliniczny & 1 \\
\hline Zachodniopomorskie & 16.0002 & Szpital Wojewódzki im. M. Kopernika w Koszalinie & 1 \\
\hline
\end{tabular}




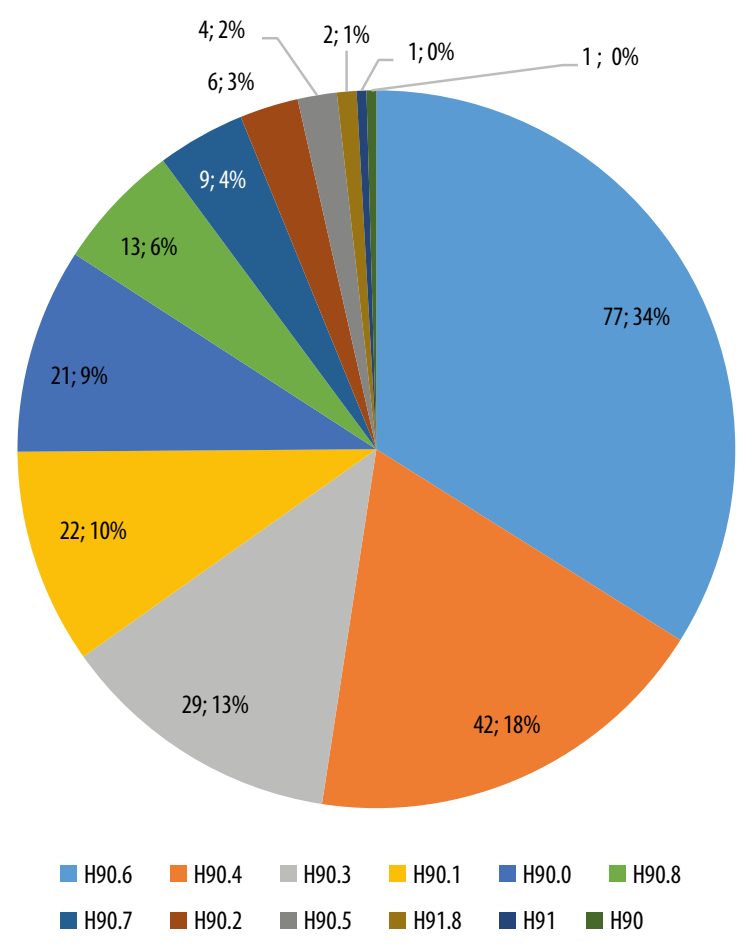

Rycina 7. Struktura hospitalizacji według głównej przyczyny [30] Figure 7. Structure of hospitalization by the main cause [30]

Największą liczbę świadczeń udzielili Instytut Fizjologii i Patologii Słuchu (Kajetany) - 43 hospitalizacje (19\%) oraz Szpital Kliniczny im. Heliodora Święcickiego Uniwersytetu Medycznego im. Karola Marcinkowskiego w Poznaniu - 30 hospitalizacji (13\%).
Najczęściej zgłaszanym rozpoznaniem i główną przyczyną leczenia szpitalnego była głuchota mieszana przewodzeniowa i czuciowo-nerwowa obustronna - 77 (34\%) hospitalizacji. Procentowy podział struktury hospitalizacji według głównej przyczyny został przedstawiony na rycinie 7 . Na wykresie uwzględnione zostały następujące przyczyny [31]:

- H90.6 Głuchota mieszana przewodzeniowa i czuciowo-nerwowa obustronna / głuchota wrodzona mieszana obustronna,

- H90.4 Głuchota czuciowo-nerwowa jednostronna bez upośledzenia słuchu po stronie przeciwnej / głuchota wrodzona odbiorcza jednostronna, utrata słuchu odbiorcza jednostronna,

- H90.3 Głuchota czuciowo-nerwowa obustronna / głuchota wrodzona odbiorcza obustronna, utrata słuchu odbiorcza obustronna,

- H90.1 Gluchota przewodzeniowa jednostronna bez upośledzenia słuchu po stronie przeciwnej / głuchota wrodzona przewodzeniowa jednostronna, utrata słuchu przewodzeniowa jednostronna,

- H90.0 Głuchota przewodzeniowa obustronna / głuchota wrodzona przewodzeniowa obustronna, utrata słuchu przewodzeniowa obustronna,

- H90.8 Głuchota mieszana przewodzeniowa i czuciowo-nerwowa, nieokreślone / głuchota wrodzona mieszana BNO [czyli bliżej nieokreślona - przyp. aut.],

- H90.7 Głuchota mieszana przewodzeniowa i czuciowo-nerwowa jednostronna bez upośledzenia słuchu po stronie przeciwnej / głuchota wrodzona mieszana jednostronna,

- H90.2 Głuchota przewodzeniowa, nieokreślona / głuchota wrodzona przewodzeniowa BNO, utrata słuchu przewodzeniowa $\mathrm{BNO}$,

- H90.5 Głuchota czuciowo-nerwowa nieokreślona / głuchota wrodzona odbiorcza BNO, utrata słuchu

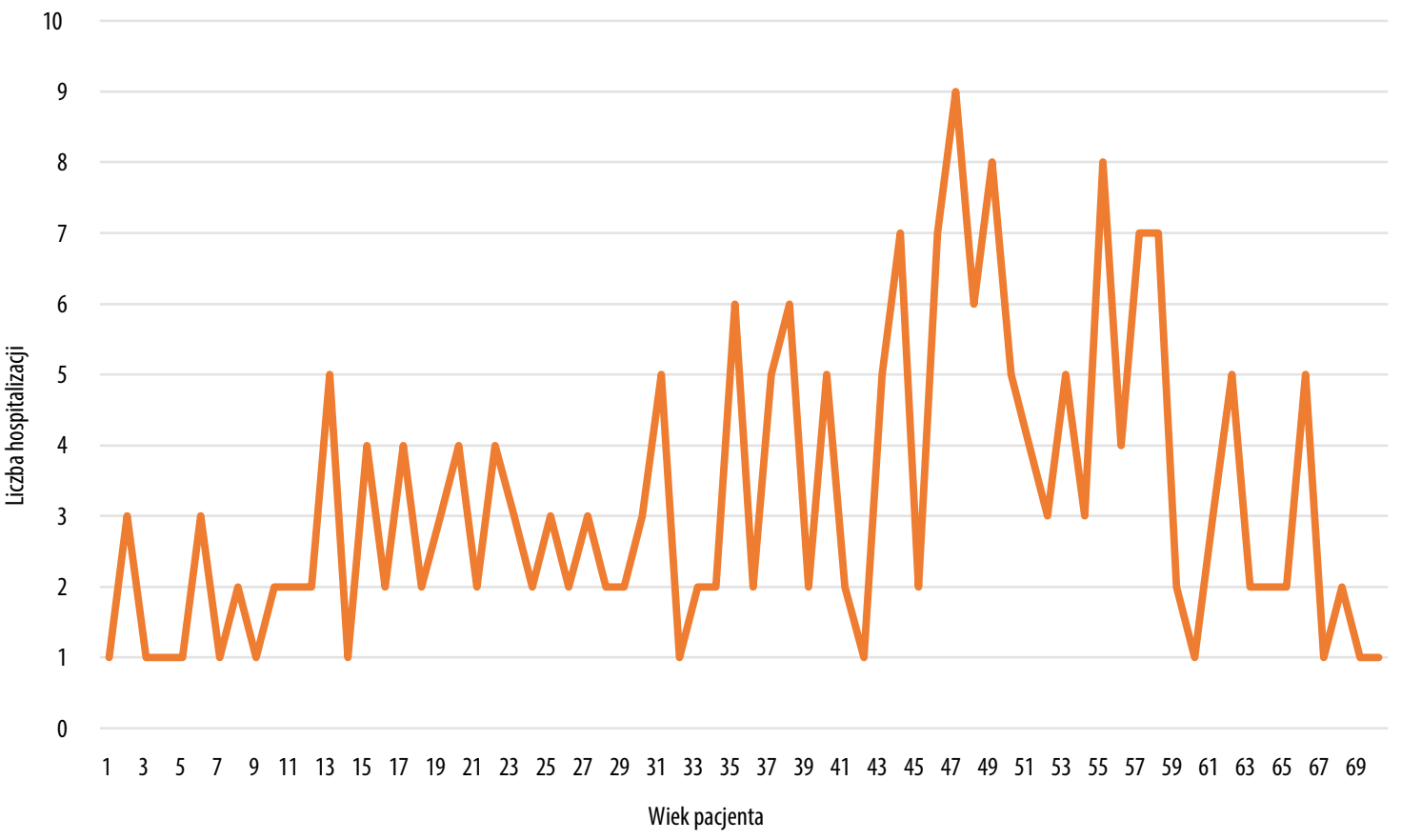

Rycina 8. Struktura hospitalizacji według wieku pacjenta [30]

Figure 8. Structure of hospitalization by patient's age [30] 
odbiorcza BNO, ubytek słuchu (ośrodkowy) (nerwowy BNO) (percepcyjny) (czuciowy),

- H91.8 Inne określone postacie głuchoty,

- H91 Inna głuchota, nie obejmuje: zaburzenia percepcji (H93.2), głuchota sklasyfikowana pod numerem H90.-, upośledzenie słuchu spowodowane obecnością woskowiny (H61.2), utrata słuchu spowodowana hałasem (H83.3), głuchota psychogenna (F44.6), przejściowa głuchota niedokrwienna (H93.0),

- H90 Głuchota przewodzeniowa i czuciowo-nerwowa (odbiorcza), obejmuje: głuchota wrodzona. Nie obejmuje: głuchoniemota nieklasyfikowana gdzie indziej (H91.3), głuchota BNO (H91.9), ubytek słuchu: BNO (H91.9), spowodowany hałasem (H83.3), ototoksyczny (H91.0), nagły (idiopatyczny) (H91.2).

Analizując strukturę hospitalizacji pod względem wieku pacjentów, którym udzielono świadczeń, stwierdzono, że leczeniem objęte zostały osoby w wieku od 1. do 69 . roku życia. Najwięcej świadczeń otrzymali pacjenci w wieku powyżej 40. roku życia. Rycina 8. przedstawia dokładny rozkład sprawozdanych hospitalizacji odnoszący się do wieku pacjenta w momencie udzielania świadczenia.

W 2014 roku najwięcej hospitalizacji zostało zrealizowanych w 3 województwach: mazowieckim (66), wielkopolskim (39) oraz śląskim (22). Najmniej świadczeń szpitalnych zrealizowało województwo zachodniopomorskie (3). Omawiane świadczenia udzielane były zarówno mieszkańcom danego województwa, jak i osobom spoza regionu (rycina 9).

W województwie mazowieckim wykonano najwięcej hospitalizacji - 66 , z czego 3\% stanowiły świadczenia dla dzieci. Średni wiek dorosłego pacjenta to 47 lat, natomiast

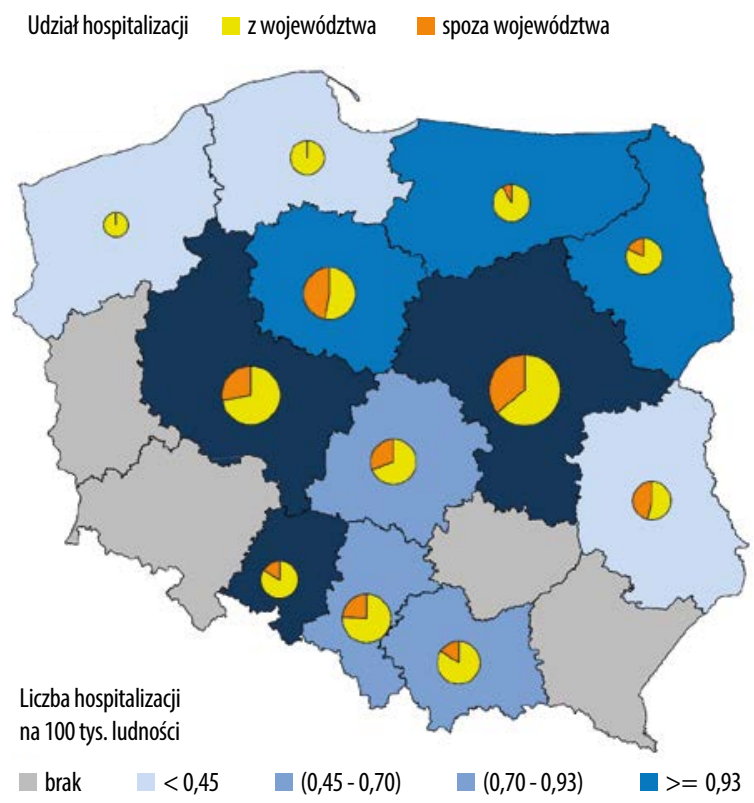

Rycina 9. Udział województw w realizacji hospitalizacji z uwzględnieniem świadczeń dla osób z województwa oraz spoza regionu [30]

Figure 9. Participation of voivodships in the implementation of hospitalization including benefits for people from the region and from outside the region [30] dziecka - 15. Pacjentom spoza województwa mazowieckiego udzielono 56,1\% wszystkich świadczeń szpitalnych. Długość pobytu w szpitalu wynosiła średnio: dla dorosłego pacjenta - 4 dni, a dla dziecka - 7 dni. W Wielkopolsce zrealizowano 39 hospitalizacji dla 39 pacjentów, z czego $38,5 \%$ hospitalizacji dotyczyło pacjentów spoza tego województwa. Wszyscy pacjenci byli osobami dorosłymi. Ich średni wiek wyniósł 49 lat, a średni czas pobytu w szpitalu - 2 dni. Na Śląsku przyjęto 21 pacjentów na 22 hospitalizacje, a 4,5\% stanowiły hospitalizacje dzieci. Średni wiek pacjentów: dorośli - 50 lat, dzieci - 12 lat. Średni czas trwania pobytu szpitalnego zarówno dla dzieci, jak i osób dorosłych wyniósł 1 dzień. Hospitalizacje dla osób spoza województwa stanowiły $38,1 \%$ wszystkich wykonanych. Najmniej hospitalizacji odnotowano w województwie zachodniopomorskim - zaledwie 3. Wszystkie dotyczyły dorosłych pacjentów zamieszkujących województwo. Ich średni wiek wyniósł 46 lat, a średni czas pobytu w szpitalu - 3 dni. Szczegółowe dane dotyczące świadczeń szpitalnych w poszczególnych województwach zostały przedstawione w tabeli 2 .

Ogólny średni czas trwania hospitalizacji we wszystkich analizowanych województwach był podobny i wyniósł: w przypadku dorosłych 3-4 dni, a dzieci - 2 dni. Dokładny rozkład został przedstawiony na rycinie 10 .

\section{Dyskusja}

Implanty ucha środkowego oraz zakotwiczone w kości skroniowej są stosunkowo nowymi urządzeniami. Badania opisane w literaturze wskazują, że u pacjentów zdolnych do noszenia tradycyjnych aparatów słuchowych implanty wszczepiane do ucha środkowego, w porównaniu do korzyści osiąganych w przypadku zastosowania klasycznych aparatów słuchowych, umożliwiają podobną poprawę funkcjonalną [32]. Jednakże w odniesieniu do percepcji mowy w hałasie oraz jakości odbieranego dźwięku poprawa jest większa $[1,6,23,26]$. Należy podkreślić, że dla osób, które $\mathrm{z}$ różnych powodów nie mogą korzystać z klasycznych urządzeń wspomagających słyszenie, implanty ucha środkowego stanowią główną i realną opcję leczenia.

Implanty na przewodnictwo kostne stosowane są najczęściej w przypadku utrudnionej naturalnej transmisji dźwięku do ucha wewnętrznego, np. ze względu na uszkodzenie lub zatkanie czy zarośnięcie ucha środkowego. Konsensus Polskiego Towarzystwa Otolaryngologów Chirurgów Głowy i Szyi z 2011 roku podaje, że systemy implantów zakotwiczonych w kości są sprawdzoną i skuteczną metodą leczenia pacjentów cierpiących na niedosłuchy typu przewodzeniowego, mieszanego oraz osób z jednostronną głuchotą [33]. Implanty te nie powinny być jednak traktowane jako zamienniki konwencjonalnych aparatów słuchowych, lecz jako skuteczne rozwiązanie dla osób z określonymi wskazaniami, gdy klasyczny aparat słuchowy nie może być zastosowany [34].

\section{Wnioski}

Dostępność implantów ucha środkowego oraz na przewodnictwo kostne jest w miarę równomierna na terenie kraju. Jednak większość usług związanych z tego typu 
Tabela 2. Zestawienie wykonanych hospitalizacji w 2014 roku z podziałem na poszczególne województwa z uwzględnieniem: hospitalizacji dorosłych i dzieci, odsetka hospitalizacji osób spoza województwa, średniego wieku pacjentów oraz średniego czasu pobytu w szpitalu. Kolejność - według liczby wykonanych hospitalizacji [30]

Table 2. List of performed hospitalizations in 2014 with division into individual voivodships including: hospitalization of adults and children, percentage of hospitalization of people from outside the province, average age of patients and average length of stay in hospital. The sequence according to number of hospitalizations [30]

\begin{tabular}{|c|c|c|c|c|c|c|c|c|c|}
\hline Województwo & 趂 & 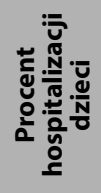 & 蛋 & 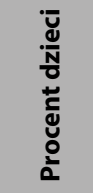 & 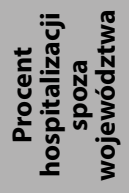 & 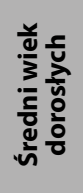 & 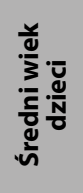 & 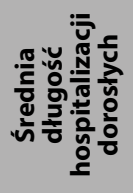 & 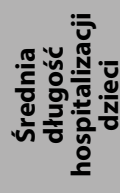 \\
\hline Mazowieckie & 66 & $3,0 \%$ & 66 & $3,0 \%$ & $56,1 \%$ & 47 & 15 & 4 & 7 \\
\hline Wielkopolskie & 39 & $x$ & 39 & $0,0 \%$ & $38,5 \%$ & 49 & $x$ & 2 & $x$ \\
\hline Śląskie & 22 & $4,5 \%$ & 21 & $4,8 \%$ & $31,8 \%$ & 50 & 12 & 1 & 1 \\
\hline Kujawsko-pomorskie & 19 & $21,1 \%$ & 19 & $21,1 \%$ & $89,5 \%$ & 50 & 12 & 2 & 2 \\
\hline Łódzkie & 16 & $81,3 \%$ & 14 & $78,6 \%$ & $43,8 \%$ & 46 & 11 & 5 & 2 \\
\hline Małopolskie & 16 & $x$ & 16 & $0,0 \%$ & $18,8 \%$ & 56 & $x$ & 2 & $x$ \\
\hline Warmińsko-mazurskie & 11 & $x$ & 11 & $0,0 \%$ & $9,1 \%$ & 44 & $x$ & 2 & $x$ \\
\hline Opolskie & 10 & $x$ & 10 & $0,0 \%$ & $20,0 \%$ & 55 & $x$ & 2 & $x$ \\
\hline Podlaskie & 9 & $x$ & 9 & $0,0 \%$ & $22,2 \%$ & 47 & $x$ & 3 & $x$ \\
\hline Pomorskie & 9 & $x$ & 9 & $0,0 \%$ & $0,0 \%$ & 66 & $x$ & 2 & $x$ \\
\hline Lubelskie & 7 & $x$ & 7 & $0,0 \%$ & $85,7 \%$ & 41 & $x$ & 3 & $x$ \\
\hline Zachodniopomorskie & 3 & $x$ & 3 & $0,0 \%$ & $0,0 \%$ & 46 & $x$ & 3 & $x$ \\
\hline
\end{tabular}

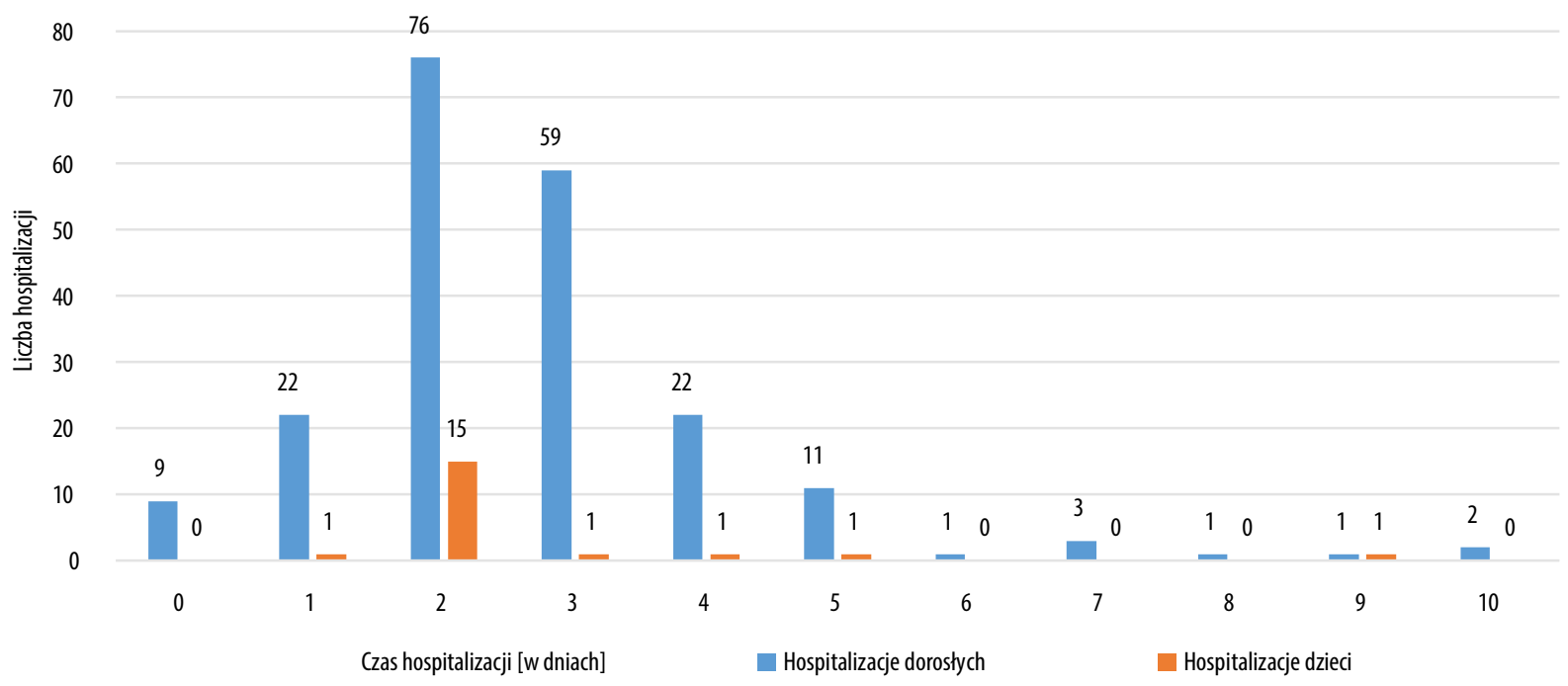

Rycina 10. Liczba hospitalizacji w zależności od czasu trwania [30]

Figure 10. Number of hospitalizations depending on the duration [30]

urządzeniami świadczona jest w województwie mazowieckim. Cztery województwa w ogóle nie udzielały tego typu świadczeń: podkarpackie, świętokrzyskie, lubuskie oraz dolnośląskie. W przyszłości należałoby zastanowić się nad możliwością zmian w obszarze dostępności udzielanych świadczeń, tak aby była ona równomierna na terenie całego kraju. Zaprezentowane dane wskazują, że główną grupę odbiorców tego typu implantów stanowią osoby dorosłe, powyżej 40. roku życia. Według danych GUS zmiany demograficzne, jakie zajdą w okresie od 2017 do
2050 roku, spowodują znaczny wzrost liczby osób w wieku 60 lat i więcej. Prognozy przewidują, że w 2050 roku grupa wiekowa powyżej 60. roku życia będzie stanowić $40 \%$ populacji Polski [35]. W związku z tym liczba osób, która może lub będzie mogła korzystać z urządzeń wszczepialnych do ucha środkowego oraz na przewodnictwo kostne, z roku na rok będzie się zwiększać. Rosnące zapotrzebowanie spowodować może również konieczność zwiększenia finansowania publicznego tego typu urządzeń. 


\section{Piśmiennictwo}

1. Obrycka A, Lorens A, Piotrowska A, Skarżyński H. Implant ucha środkowego. Możliwości eliminacji niektórych ograniczeń w odbiorze dźwięku wprowadzanych przez aparaty słuchowe. Audiofonologia, 2004; 26: 91-94.

2. Lorens A, Skarżyński H. Technologia implantów ślimakowych. Now Audiofonol, 2012; 1(3): 18-23.

3. Skarżyński H, Matusiak M, Piotrowska A, Skarżyński PH. Surgical techniques in partial deafness treatment. J Hear Sci, 2012; 2(3): 9-13.

4. Skarżyński H, Góralówna M, Malesińska M, Geremek A. I Konferencja Implantów Ślimakowych. Audiofonologia, 1993; V: 233-36.

5. Skarżyński H, Lorens A, Piotrowska A. A new method of partial deafness treatment. Med Sci Monit, 2003; 9(4): 20-24.

6. Skarżyński H, Szkiełkowska A, Olszewski Ł, Mrówka M, Porowski M, Fabijańska A i wsp. Program stosowania implantów ucha środkowego i implantów zakotwiczonych w kości skroniowej na przewodnictwo kostne w leczeniu zaburzeń słuchu. Now Audiofonol, 2015; 4(1): 9-23.

7. Mudry A, Tjellström A. Historical background of bone conduction hearing devices and bone conduction hearing aids. Adv Otorhinolaryngol, 2011; 71: 1-9.

8. Verhaert N, Desloovere C, Wouters J. Acoustic hearing implants for mixed hearing loss: a systematic review. Otol Neurotol, 2013; 34: 1201-09.

9. Olszewski Ł, Ratuszniak A, Obrycka A, Porowski M, Skarżyński PH, Pastuszak A i wsp. Middle Ear Implant - a chance for elimination of certain restrictions on sound reception tied with the hearing aids in the partial deafness treatment. 10th ESPCI Athens Medimond, 2011: 21-28.

10. Dumon T. Vibrant Soundbridge middle ear implant in otosclerosis: technique - indication. Adv Otorhinolaryngol, 2007; 65: 320-22.

11. Rydzewski B, Pruszewicz A. Kwalifikacja pacjentów i technika wszczepiania aparatów słuchowych zakotwiczanych (BAHA) na podstawie doświadczeń własnych. Otolaryngol Pol, 1995; 49 (Supl. 19): 461-64.

12. Mrówka M. Zastosowanie tytanowych zaczepów osteointegracyjnych w otorynolaryngologii (praca na stopień doktora nauk medycznych). WUM; 2012.

13. Skarżyński PH, Osińska K, Olszewski Ł, Ratuszniak A, Skarżyński H. Baha Attract bone conduction system-review of the patients and evaluation of the first results in Poland. 14th Symposium on Cochlear Implants in Children, 11-13. XII 2014, Nashville, USA.

14. Skarżyński H, Mrówka M, Skarżyński PH, Olszewski Ł, Ratuszniak A. Surgical experience with Baha Attract. 13th International Conference on Cochlear Implants and other Implantable Auditory Technologies, 18-21 VI 2014, Munich, Germany.

15. Skarżyński PH, Osińska K, Olszewski Ł, Ratuszniak A, Skarżyński H. Baha Attract bone conduction system-review of the patients and evaluation of the first results in Poland, 14th Symposium on Cochlear Implants in Children, 11-13 XII 2014, Nashville, USA.

16. Ratuszniak A, Mrówka M, Skarżyński PH, Skarżyński H. Urządzenia wszczepialne na przewodnictwo kostne - zasada działania oraz wskazania. Now Audiofonol, 2017; 6(3): 29-34.

17. Pfiffner F, Kompis M, Flynn M, Asnes K, Arnold A, Stieger C. Benefits of low-frequency attenuation of baha ${ }^{\circledR}$ in single-sided sensorineural deafness. Ear Hear 2011; 32(1): 40-45.
18. Sprinzl GM, Wolf-Magele A. The Bonebridge Bone Conduction Hearing Implant: Indication criteria, surgery and a systematic review of the literature. Clin Otolaryngol, 2016; 41(2): 131-43.

19. Amonoo-Kuofi K, Kelly A, Neeff M, Brown CR. Experience of bone-anchored hearing aid implantation in children younger than 5 years of age. Int J Pediatr Otorhinolaryngol, 2015; 79(4): 474-80.

20. MED-EL; https://www.medel.com [dostęp: 30.10.2018].

21. Berenholz LP, Burkey JM, Lippy WH. Use of a bone-anchored hearing aid for functional single-sided deafness. Otolaryngol Head Neck Surg, 2007; 137(3): 522-23.

22. Hol MK, Bosman AJ, Snik AF, Mylanus EA, Cremers CW. Bone-anchored hearing aids in unilateral inner ear deafness: an evaluation of audiometric and patient outcome measurements. Otol Neurotol, 2005; 26(5): 999-1006.

23. Skarżyński H, Obrycka A, Piotrowska A, Lorens A. Zastosowanie implantu ucha środkowego u pacjenta z odbiorczym, wysokoczęstotliwościowym ubytkiem słuchu - studium przypadku. Otolaryngol Pol, 2008; 62(4): 606-12.

24. Barbara M, Manni V, Monini S. Totally implantable middle ear device for rehabilitation of sensorineural hearing loss: preliminary experience with the Esteem, Envoy. Acta Otolaryngol, 2008; 31: 1-4.

25. Bruschini L, Forli F, Passetti S, Bruschini P, Berrettini S. Fully implantable Otologics MET Carina $\left.{ }^{(\mathrm{r}}\right)$ device for the treatment of sensorineural and mixed hearing loss: Audio-otological results. Acta Otolaryngol, 2010; 130(10): 1147-53.

26. de Abajo J, Sanhueza I, Giron L, Manrique M. Experience with the active middle ear implant in patients with moderate-to-severe mixed hearing loss: indications and results. Otol Neurotol, 2013; 34(8): 1373-79.

27. Zwartenkot JW, Hashemi J, Cremers CW, Mulder JJ, Snik AF. Active middle ear implantation for patients with sensorineural hearing loss and external otitis: long-term outcome in patient satisfaction. Otol Neurotol, 2013; 34(5): 855-61.

28. Maurer J, Savvas E. The Esteem System: a totally implantable hearing device. Adv Otorhinolaryngol, 2010; 69: 59-71.

29. Olszewski Ł. Urządzenia wszczepialne do ucha środkowego - przegląd. Now Audiofonol, 2013; 2(5): 15-22.

30. Rozporządzenie Ministra Zdrowia $z$ dnia 26 marca 2015 r. w sprawie zakresu treści map potrzeb zdrowotnych (Dz.U. 2015 poz. 458). Mapa potrzeb zdrowotnych dla Polski; http://www.mpz. mz.gov.pl/wp-content/uploads/sites/4/2018/01/polska-1.pdf [dostęp: 2.02.2019]

31. World Health Organization. Międzynarodowa Statystyczna Klasyfikacja Chorób i Problemów Zdrowotnych, X Rewizja, Tom I, wydanie 2008. Centrum Systemów Informacyjnych Ochrony Zdrowia, 2012; s. 309; https://www.csioz.gov.pl/fileadmin/user_ upload/Wytyczne/statystyka/icd10tomi_56a8f5a554a18.pdf [dostęp: 5.11.2018].

32. Middle Ear Implants for the Treatment of Hearing Loss. Final STE Report. December 2011; https://open.alberta.ca/dataset/6c2d9c40-724a-4275-8a02.../ahtdp-mei-uofa-ste.pdf [dostęp: 25.10.2018].

33. Durko T, Jurkiewicz D, Kantor I, Klatka J, Kuczkowski J, Niemczyk K i wsp. Konsensus na temat leczenia niedosłuchów przy zastosowaniu implantów zakotwiczonych w kości. Łódź, 2011; http://www.otolaryngologia.org.pl/orl2/pdf/zalecenia/ konsensus_leczenie_niedosluchow_implanty_zakotwiczone.pdf [dostęp: 6.11.2018]. 
34. Crowson MG, Tucci DL. Mini Review of the Cost-Effectiveness of Unilateral Osseointegrated Implants in Adults: Possibly Cost-Effective for the Correct Indication. Audiol Neurotol, 2016; 21: 69-71.
35. Główny Urząd Statystyczny. Prognoza ludności na lata 20142050 - aneks; http://stat.gov.pl/obszary-tematyczne/ludnosc/ prognoza-ludnosci/prognoza-ludnosci-na-lata-2014-2050opracowana-2014-r-,1,5.html [dostęp: 30.03.2019]. 